\section{Hypercalcaemia in Thyrotoxicosis}

Brit. med. F., 1965, 1, 169

Hypercalcaemia is now well recognized as a complication of thyrotoxicosis. It is the purpose of this paper to record a case of severe thyrotoxicosis and biochemical changes suggesting hyperparathyroidism. The changes were corrected by treatment of the thyrotoxicosis.

\section{CAse Report}

A man aged 28 years was first seen on 17 March 1960, when he gave a history of having epigastric discomfort, vomiting, and eructation for four weeks. He had lost more than $20 \mathrm{lb}$. $(9 \mathrm{~kg}$.) in weight during the preceding few weeks, and he had noticed thirst and polyuria. A succussion splash was heard, and pyloric stenosis was considered as the likely diagnosis. After admission four days later slight ocular prominence was noted, but he had no goitre or tremor. His pulse rate was 100 per minute, and his blood-pressure was $120 / 60 \mathrm{~mm}$. Hg. His serum sodium was $144 \mathrm{mEq} / 1$., chlorides 100 $\mathrm{mEq} / \mathrm{l}$., potassium $4.5 \mathrm{mEq} / \mathrm{l}$., alkali reserve 54 vol. \%, blood urea $50 \mathrm{mg} . \%$. The fasting gastric residue was $10 \mathrm{ml}$. on two occasions. A barium meal revealed some pylorospasm, but no organic lesion.

There was no radiological evidence of osteoporosis. On three occasions his sleeping pulse rate was above 90 per minute and his basic metabolic rate was found to be $+35 \%$. Radioactive iodine studies revealed a 24 -hour neck uptake of $77 \%$ of the dose, and potassium perchlorate $1,000 \mathrm{mg}$. daily was started. His symptoms continued, and altogether he lost $17 \mathrm{lb}$. $(8 \mathrm{~kg}$.) in weight during the first two weeks in hospital. His condition then deteriorated sharply: his vomiting increased, and he became dehydrated and developed signs suggesting an acute thyrotoxic myopathy. His blood urea was found to be $106 \mathrm{mg} . \%$, serum sodium $178 \mathrm{mEq} / 1$, chlorides $101 \mathrm{mEq} / \mathrm{l}$. His serum calcium was found to be $13.5 \mathrm{mg}$ \% (see Table). Intravenous therapy and oral Lugol's iodine were started, with immediate improvement in his condition. The initial alkaline phosphatase was 16 King-Armstrong units \%, and the serum phosphate $2.6 \mathrm{mg} . \%$, but the lowest serum phosphate reading obtained was $1.8 \mathrm{mg} . \%$. The blood samples were obtained without fasting. The urinary calcium excretion was $440 \mathrm{mg}$. in 24 hours on unlimited diet at the height of the illness, but after three days during which calcium intake was restricted to $265 \mathrm{mg}$. calcium per day the daily urinary excretion dropped to $275 \mathrm{mg}$. Nine days after his sudden deterioration the tubular phosphate reabsorption was $81 \%$ and the phosphate/ creatinine clearance (employing endogenous creatinine) was 0.19 both being normal. The phosphate-excretion index was also normal at +0.075 . These tests performed after the vomiting had ceased suggested that the biochemical disturbance was due to the thyrotoxicosis, and in fact anti-thyroid treatment resulted in the biochemistry reverting to normal after 11 days. Treatment has ceased, and there has been no relapse two years after stopping treatment.

\begin{tabular}{|c|c|c|c|c|c|c|c|c|c|}
\hline \multicolumn{10}{|c|}{ Results of Biochemical Tests } \\
\hline Date & $\underset{\stackrel{o}{0}}{\stackrel{+}{N}}$ & 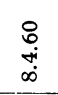 & $\begin{array}{l}: \\
\stackrel{0}{+} \\
\text { ă }\end{array}$ & $\begin{array}{l}: \\
\stackrel{0}{+} \\
\stackrel{-}{-}\end{array}$ & $\begin{array}{l}: \\
\dot{0} \\
\dot{m}\end{array}$ & $\begin{array}{l}8 \\
\stackrel{0}{0} \\
\dot{0}\end{array}$ & $\begin{array}{l}\stackrel{8}{0} \\
\underset{i}{+} \\
\text { N }\end{array}$ & $\begin{array}{l}\stackrel{8}{0} \\
\stackrel{+}{\infty} \\
i\end{array}$ & 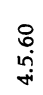 \\
\hline Urea (mg. \%) & 50 & 106 & 60 & 57 & 48 & 59 & - & 31 & 28 \\
\hline $\begin{array}{c}++\mathrm{Ca} \\
(\mathrm{mg} \%)\end{array}$ & - & - & 13.5 & 13 & 13 & 13 & 13 & 11.5 & 11 \\
\hline Phosphate & - & - & $2 \cdot 6$ & $1 \cdot 8$ & $2 \cdot 2$ & $2 \cdot 3$ & $2 \cdot 5$ & $2 \cdot 4$ & $3 \cdot 5$ \\
\hline $\begin{array}{l}\text { Alkaline } \\
\text { phosphatase } \\
\text { (K-A units) }\end{array}$ & - & - & 16 & 15 & 12 & 10 & - & 13 & 13 \\
\hline
\end{tabular}

\section{Comment}

A similar case is described by Epstein et al. (1958), but the biochemical changes were attributed to recalcification of bone during treatment.
Elevation of the serum-calcium level in thyrotoxicosis, but without alteration in the serum phosphate or alkaline phosphatase, is recorded by many authors (Stanley and Fazekas, 1949 ; Rose and Boles, 1953 ; Pribek and Meade, 1957 ; Kleeman et al., 1958 ; Bortz et al., 1961). Laake (1955), Krane et al. (1956), and Cook et al. (1959) note alteration in the alkaline phosphatase alone, this only occurring during treatment in the patients described by the last-named authors. Cook et al. also note that the plasma phosphate is normal or elevated, with which Puppel et al. (1945) agree, and Frame and Durham (1959) suggest that a low serum phosphate accompanying hypercalcaemia in thyrotoxicosis suggests coincidental hyperparathyroidism.

The precise mechanism of the disturbance in calcium metabolism is not known, but it has been suggested that it is secondary to the osteoporosis produced by thyroid hormone on bone. Krane et al. (1956) employing isotopic calcium demonstrated increased bone formation and destruction, which they considered responsible for the changes in calcium metabolism. Cope and Donaldson (1937) record details of a patient with thyrotoxicosis which was treated surgically and in whom tetany developed post-operatively owing to hypoparathyroidism. The tetany disappeared when the thyrotoxicosis recurred, but reappeared when anti-thyroid drugs were given. Increased faecal and urinary loss has been shown by Aub et al. (1929), Robertson (1942), Puppel et al. (1945), Cook et al. (1959), and Wayne (1960). Wayne notes that the absorption of calcium appears to be normal, and suggests that the excessive urinary loss may be due in part to an increased glomerular filtration rate, or to the hypercalcaemia.

Bortz et al. (1961) investigated the tubular reabsorption of phosphate in 13 thyrotoxic patients who also had hypercalcaemia. It was abnormal in two, and both were later found to have parathyroid tumours. In a third in whom the result was borderline it had returned to normal after anti-thyroid treatment, indicating that the hypercalcaemia was due to thyrotoxicosis. Similar conclusions were drawn from the finding of a normal result in the case recorded in our paper.

I am grateful to Dr. Ronald Jones, under whose care this patient was admitted, for permission to publish and for his help in the preparation of the paper, and to Dr. J. D. N. Nabarro for his helpful criticism.

\author{
P. B. GUY.ER,* M.R.C.P., \\ Late Medical Registrar, Ipswich and East Suffolk \\ Hospital, Ipswich.
} * Present address: Diagnostic $X$-ray Department, St. Thomas's Hospital,
London S.E.1.

\section{REFERENCES}

Aub, J. C., Bauer, W., Heath, C., and Ropes, M. (1929). F. clin. Invest., 7, 97. Bortz, W., Eisenberg, E., Bowers, C. Y., and Pont, M. (1961). Ann.
intern. Med., 54, 610.

Cook, P. B., Nassim, J. R., and Collins, J. (1959). Quart. F. Med., 28, 505 .

Cope, O., and Donaldson, G. A. (1937). 7 clin. Invest., 16, 329.

Epstein, F. H., Freedman, L. R., and Levitin, H. (1958). New Engl. F. Med., 258, 782.

Frame, B., and Durham, R. H. (1959). Amer. F. Med., 27, 824. Kleeman, C. R., Tuttle, S., and Bassett, S. H. (1958). F. clin. Endocr.,
18, 477.

Krane, S. M., Brownell, G. L., Stanbury, J. B., and Corrigan, H. (1956). f. clin. Invest., 35, 874.

Laake, H. (1955). Acta med. scand., 151, 229.

Pribek, R. A., and Meade, R. C. (1957). Arch. intern. Med., 100, 994.

Puppel, I. D., Gross, H. T., McCormick, E. K., and Herdle, E. (1945). Surg. Gynec. Obstet., 81, 243.

Robertson, J. D. (1942). Lancet, 1, 672.

Rose, E., and Boles, R. S. (1953). Med. Clin. N. Amer., 37, 1715.

Stanley, M. M., and Fazekas, J. (1949). Amer. 7. Med., 7, 262.

Wayne, E. J. (1960). Brit. med. F., 1, 78. 